\title{
Meningkatkan Kecerdasan Logika Matematika Anak Usia Dini melalui Media Interaktif Puzzle Angka
}

\author{
Wahyun Nabilatun Nabighoh ${ }^{1}{ }^{凶}$, Mustaji $^{2}$, Hendratno $^{1}$ \\ Pendidikan Dasar, Universitas Negeri Surabaya, Indonesia(1) \\ Teknologi Pendidikan, Universitas Negeri Surabaya, Indonesia(2) \\ DOI: $\underline{10.31004 / \text { obsesi.v6i4.2410 }}$
}

\begin{abstract}
Abstrak
Penelitian ini dilatar belakangi oleh belum berkembangnya kecerdasan logika matematika anak. Berdasarkan latar belakang masalah yang dipaparkan, maa dapat dirumuskan masalah penelitian ini, bagaimana peningkatan kkecerdasan logika matematika anak usia dini melalui media interaktif puzzle angka?. Adapun tujuan dari penelitian ini untuk mengetahui cara meningkatkan kecerdasan logika matematika anak usia dini dengan menggunakan media interaktif puzzle angka. Metode yang digunakan yaitu sampel dari hasil penelitian terdahulu yang dilakukan oleh peneliti sebelumnya dan berhubungan dengan media interaktif, puzzle angka, dan kecerdasan logika matematika anak usia dini. Sampel pada penelitian ini juga terfokus pada anak usia dini. Kajian penelitian yang relevan dan terdahulu yang terkumpul dari artikel ilmiah yang telah dipublikasikan baik artikel ilmiah internasional, internasional bereputasi, dan nasional. Selain itu kajian ini dilengkapi sumber data dari buku dan peneltian lainnya yang relevan. Dalam proses menganalisis data penelitian menggunakan metode berpikir induktif. Kebaruan dalam penelitian ini yakni menggunakan media interaktif dengan model puzzle angka.
\end{abstract}

Kata Kunci: media interaktif; puzzle angka; logika matematika.

\begin{abstract}
This research is motivated by the undeveloped mathematical logic intelligence of children. Based on the background of the problem presented, the problem of this research can be formulated, how to increase the logical intelligence of early childhood mathematics through interactive media of number puzzles?. The purpose of this study is to find out how to improve the logical intelligence of early childhood mathematics by using interactive number puzzle media. The method used is a sample from the results of previous research conducted by previous researchers and related to interactive media, number puzzles, and early childhood mathematical logic intelligence. The sample in this study also focused on early childhood. Relevant and previous research studies that have been collected from scientific articles that have been published in international, internationally reputable, and national scientific articles. In addition, this study is complemented by data sources from books and other relevant research. In the process of analyzing research data using inductive thinking methods. The novelty in this research is the use of interactive media with a number puzzle model.
\end{abstract}

Keywords: interactive media; number puzzle; mathematical logic.

Copyright (c) 2022 Wahyun Nabilatun Nabighoh, et al.

$\triangle$ Corresponding author :

Email Address : wahyun.20022@mhs.unesa.ac.id (Surabaya, Indonesia)

Received 9 November 2021, Accepted 23 February 2022, Published 27 February 2022 


\section{PENDAHULUAN}

Dunia pendidikan senantiasa diarahkan pada peningkatan mutu sumber daya manusia terutama pendidikan anak usia dini. Anak usia dini merupakan anak yang berada direntang usia sejak lahir sampai dengan enam tahun, bersifat unik dan tidak dapat disamakan dengan orang dewasa, mengalami pertumbuhan dan perkembangan secara pesat, dimana pertumbuhan dan perkembangannya saat usia dini berpengaruh pada pertumbuhan dan perkembangannya selanjutnya. Hal ini sesuai dengan Peraturan Menteri Pendidikan Dan Kebudayaan Nomor 146 Tahun 2014 sehubungan dengan kurikulum 2013 pendidikan anak usia dini pasal 1 menyatakan bahwa pendidikan anak usia dini diselenggarakan bagi anak sejak lahir sampai enam tahun dan bukan prasyarat untuk mengikuti pendidikan dasar.

Anak usia dini dianggap sebagai masa golden age karena pada masa ini anak sedang mengalami perkembangan yang sangat baik secara fisik maupun psikis. Golden age menurut (Permendiknas, 2003) adalah masa perkembangan anak usia dini sebagai kualitas anak yang memiliki makna dan pengaruh yang luar biasa untuk kehidupan selanjutnya. Pendapat lain yaitu (Sholihah, 2018) menyatakan bahwa masa anak harus diperhatikan serius, sebab dalam masa ini merupakan masa keemasan. Anak dalam masa golden age akan mudah diasah kemampuannya dan mudah dalam diberi stimulasi serta rangsangan dari lingkungan sekitar anak. Pemberian stimulasi yang tepat akan menjadi pondasi yang penting bagi perkembangan dan kecerdasan anak pada masa yang akan datang. Menurut (Suripatty et al., 2020) kecerdasan adalah sesuatu yang dapat dikembangkan sejak usia dini, sehingga anak akan mudah menyelesaikan masalah dan memiliki kemampuan penalaran.

Jenis kecerdasan sangatlah banyak, berbagai macam jenis kecerdasan disebut multiple intelligences atau kecerdasan jamak. Tokoh penggagas multiple intelligences yakni Howard Gardner yang menyatakan bahwa kemampuan seorang individu dalam mengahadapi permasalahan dikehidupannya (Yildiz et al., 2020). Rambu stimulasi berdasarkan kecerdasan jamak dapat memberi arahan mengenai jenis stimulasi yang tepat bagi anak (Mufarizuddin, 2017). Kecerdasan jamak membuat pendidik dapat memberikan stimulasi yang tepat bagi anak agar kecerdasan yang dimiliki dapat ditonjolkan dalam diri anak. Pembelajaran yang berlandskan kecerdasan jamak akan memberi pengalaman belajar dan menghargai setiap kecerdasan anak (Zamroni, 2020). Kecerdasan jamak diantaranya kecerdasan musikal, kecerdasan kinestetik, kecerdasan bahasa, kecerdasan visual-spasial, kecerdasan interpersonal, kecerdasan intrapersonal, kecerdasan naturalis, kecerdasan spiritual, serta kecerdasan logika matematika. Kecerdasan logika matematika menurut (Nusantara \& Kediri, n.d.) yaitu kecerdasan yang berhubungan dengan kemampuan memanipulasi objek berdasarkan kriteria, menghitung, abstaksi benda konkret, dan mengenal sebab akibat. Kecerdasan logika matematika adalah kemampuan menghitung, mengukur, dan mempertimbangkan serta menyelesaikan matematika (Mustajab et al., 2020)

Pada zaman sekarang kondisi yang diharapkan oleh para ahli yakni kemampuan melejitkan kecerdasan logika matematika, yaitu keadaan anak mampu menggunakan angka dan berpikir logis untuk memahami pola tertentu yang muncul saat menghadapi masalah, seperti pola pikir, angka, visual, dan warna (Mufarizuddin, 2017). Dengan demikian, banyak sekali para orangtua yang memaksa anak belajar tanpa memperhatikan kebutuhan anak dan prinsip belajar anak. Salah satu prinsip belajar dengan anak yaitu melalui bermain. Bermain mampu meningkatkan kemampuan dan seluruh aspek potensi yang dimiliki anak (Lestariningrum \& Handini, 2017). Salah satu permainan yang menarik bagi anak guna mengembangkan kecerdasan logika matematika yaitu dengan puzzle angka. Hal ini sesuai dengan pendapat Sholihah (2018) bahwa puzzle angka akan memberikan pengalaman belajar yang efektif dibandingkan dengan media lain. Pendapat lain mengatakan bahwa dengan bermain puzzle dapat memberi kesenangan serta menurunkan kecemasan yang dirasa anak (Mubarok \& Amini, 2020). 
Dalam pemberian puzzle angka dapat menggunakan media interaktif. Media interaktif sebagai media pembelajaran yang dirasa cukup mempermudah dalam membantu proses pembelajaran. Media pembelajaran interaktif memudahkan anak dalam memahamai pembelajaran (Apriliani et al., 2020). Pembelajaran berbantuan multimedia interaktif membuat peserta didik lebih memahami, mengerti, aktif, mengaplikasikannya dalam kehidupan sehari-hari (Munawaroh et al., 2020). Menggunakan media interaktif dalam proses belajar akan sangat menyenangkan bagi anak. Hal ini bisa menjadi alibi guna mengajak anak belajar melalui permainan berbasis game. Walaupun sebuah game itu sederhana, namun anak akan senang belajar melalui game dari pada belajar dengan buku.

Upaya dalam meningkatakan logika matematika melalui media interaktif puzzle angka, harus diawasi oleh orang tua. Orang tua haruslah selektif memilih media interaktif sehingga dapat terjadinya proses pembelajaran. Media interaktif haruslah mengandung unsur pembelajaran jika digunakan dalam pendidikan (Dewi et al., 2017). Hal ini menjadi kelemahan dari media interakif dalam pembelajaran, bahwa harus dipilih selektif saat digunakan sebagai media belajar. Dengan demikian media interatif memiliki kekurangan dan kelebihannya masing-masing. Sehingga dalam penggunaannya apalagi bagi anak usia dini perlu dalam pengawasan orang tua, sehingga anak dapat mendapatkan pembelajaran yang optimal dan orang tua mampu memantau perkembangan anak.

Sehubungan dengan hal tersebut, maka penulis termotivasi untuk mengadakan penelitian kajian Pustaka dengan judul "Meningkatkan Kecerdasan Logika Matematika Anak Usia Dini Melalui Media Interaktif Puzzle Angka". Tujuan yang ingin dicapai adalah untuk mengetahui peningkatan kecerdasan logika matematika melalui media interaktif puzzle angka.

\section{METODOLOGI}

Dalam penyusunan penelitian ini menggunakan kajian Pustaka dengan rambu penelitian kualitatif dengan mengumpulkan data berupa artikel ilmiah, baik berhubungan langsung atau tidak dengan variabel penelitian. Metode pengumpulan data dilakukan dengan metode kajian literatur atau literature review. Penelitian kajian Pustaka menurut Sujarweni (2019:23) adalah kajian dari bahan dokumenter yang tertulis bisa berupa buku teks, surat kabar, majalah, surat-surat, film, catatan harian, naskah, artikel, dan sejenisnya, bahan juga didapat dari pikiran seseorang yang tetuang dalam buku atau naskah yang terpublikasikan. Terdapat tiga alasan peneliti melakukan penelitian kajian pustaka, yaitu: (1) masalah penelitian hanya dapat dijawab melalui penelitian kepustakaan; (2) kajian pustaka diperlukan satu tahap tersendiri, dimana studi awal diperlukan untuk memahami gejala terbaru yang berkembang didalam masyarakat; (3) hasil kajian pustaka dapat dipercaya dalam menjawab masalah penelitian (Wandi \& Mayar, 2020).

Adapun Langkah yang dilakukan adalah mengumpulkan data yang bersumber dari penelitian terdahulu. Penelitian menggunakan sampel dari hasil penelitian terdahulu yang dilakukan oleh peneliti sebelumnya dan berhubungan dengan media interaktif, puzzle angka, dan kecerdasan logika matematika anak usia dini. Sampel pada penelitian ini juga terfokus pada anak usia dini. Kajian penelitian yang relevan dan terdahulu yang terkumpul dari artikel ilmiah yang telah dipublikasikan dari artikel ilmiah internasional, internasional bereputasi, dan nasional. Selain itu kajian ini dilengkapi sumber data dari buku dan peneltian lainnya yang relevan.

Dalam proses menganalisis data penelitian menggunakan metode berpikir induktif. Metode berpikir induktif. Pendekatan induktif menurut Sujarweni (2019:13) yakni pola berpikir menggunakan pendekatan yang dilakukan untuk membangun sebuah teori berdasarkan hasil pengamatan atau observasi yang dilakukan secara berulang-ulang dan membentuk pola yang akan melahirkan hipotesis yang berasal dari pengamatan yang dilakukan dan barulah diperoleh sebuah teori. Metode ini menyatukan berbagai temuan informasi dari penelitian sebelumnya yang relevan terkait dengan media interaktif, puzzle angka, dan kecerdasan logika matematika anak usia dini untuk diabstraksi menjadi suatu 
pemikiran baru yang dapat dipertanggungjawabkan kebenarannya. Proses analisis data penelitian disajikan pada gambar 1.

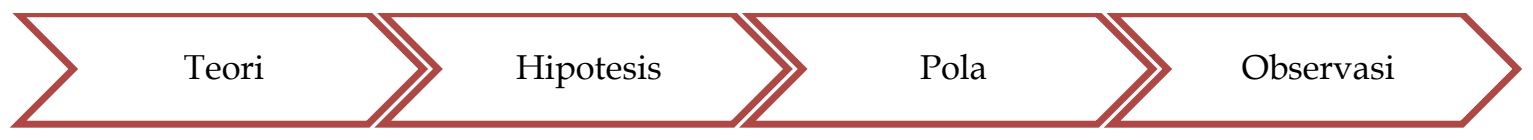

\section{Gambar 1. Analisis data penelitian}

Sumber: Sujarweni (2019:13)

Berdasarkan hal tersebut, maka peneliti menggunakan kerangka berpikir seperti disajikan pada gambar 2.

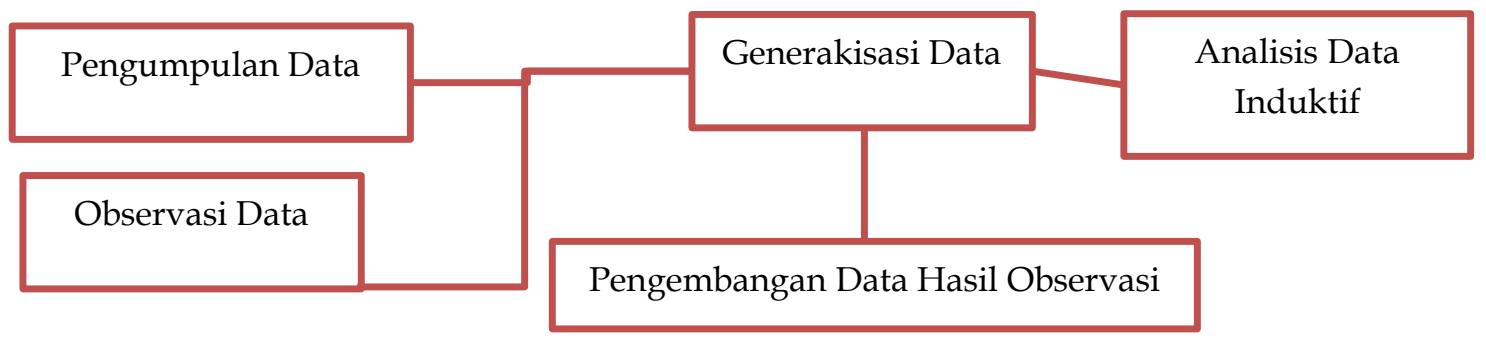

\section{Gambar 2. Kerangka berpikir}

\section{HASIL DAN PEMBAHASAN}

\section{Pembelajaran Dengan Media Interaktif}

Perkembangan dan dukungan teknologi digital telah memberikan peluang baru untuk memberikan pembelajaran dalam bentuk game edukasi digital pada anak usia dini. Karena anak-anak sangat terkait dengan permainan, maka game edukasi digital menjadi langkah strategis untuk memberikan pengalaman baru pembelajaran (Setiawan et al., 2019). Anak usia dini sangat terkait dengan pembelajaran yang dikemas di dalam permainan. Pembelajaran pada usia ini, menekankan bahwa anak-anak memperoleh beberapa keterampilan melalui permainan (Zaini et al., 2017). Sehingga, penggunaan game edukasi digital memberikan pengalaman pembelajaran interaktif, menyenangkandan interaksi sosial sesuai kebutuhanperkembangannya. Pertama, anak-anak membutuhkan rangsangan untuk mengembangkan keterampilan motorik halus sebelum menuju pada ranah kognitif.

Namun, adanya kekurangan bermain game digadget membuat para pendidik harus berputar otak dalam membuat permainan yang menarik bagi anak. Anak-anak sudah sangat terbiasa memainkan game yang tidak sesuai dengan usianya yang banyak mengandung unsur kekerasan dan pornoaksi sehingga bisa saja mempengaruhi perilaku dan pikiran anak. Oleh sebab itu pendidik bisa memilih alternatif dengan merancang game menarik yang juga bisa dimainkan diperangkat lunak baik $\mathrm{hp}$ atau laptop, salah satunya bermain game sederhana sebagai media interaktif sebagai cara belajar anak. Menurut (Susilawati \& Satriawan, 2018) guru dapat memanfaatkan multimedia yang menguntungkan dan memperlancar proses belajar mengajar dan juga dapat merangsang anak aktif dalam belajar jika sekiranya suatu pokok bahasan memerlukanlebih dari satu macam media pembelajaran.

Media pembelajaran dengan berupa game yang berisi program yang dapat berinteraksi dengan pengguna dengan berbantuan komputer atau laptop. pada anak usia dini menggunakan salah satu media pembelajaran agar memudahkan peserta didik dalam memahami pesan yang disampaikan yaitu menggunakan multimedia interaktif. Pembelajaran berbantuan multimedia interaktif ini berupaya membuat peserta didik lebih memahami, mengerti, aktif, mengaplikasikannya dalam kehidupan sehari-hari (Munawaroh et al., 2020) 
Media interaktif adalah media praktis dan didalam media tersebut memuat banyak materi, sehingga mempermudah guru dalam penyampaian materi dan dapat menarik minat anak untuk belajar. Pembelajaran media interaktif sangat menarik, mudah dipahami dan tidak cepat membosankan dikarenakan Media Interaktif ini adalah teknik belajar sambil bermain yang dikemas sesuai untuk anak usia dini (Cahyati et al, 2018). Dengan adanya pembelajaran membangun media interaktif belajar anak balita dalam mengenal huruf dan angka dengan demikian akan mempermudah anak balitauntuk mengenal huruf dan angka tanpa paksaan dari orang tuanya (Susilawati \& Satriawan, 2018).

\section{Puzzle Angka}

Media puzzle angka akan memberikan pengalaman yang lebih efektif atau baikjika dibandingkan dengan media pembelajaran lainnya. Berhitung untuk anak usia dini disebut pula kegiatan menyebutkan urutan bilangan atau membilang buta. Anak menyebutkan urutan bilangan tanpa menghubungkan dengan benda-benda konkret (Sholihah, 2018). Puzzle merupakan alat permainan edukatif yang menyenangkan yang bisa digunakan untuk mengembangkan kemampuan berpikir atau kemampuan kognitif anak untuk memecahkan masalah (Kristianti et al., 2018). Puzzle angka adalah APE yang dapat dimanfaatkan sebagai media menstimulasi kecerdasan matematika-logika(Syukron Al Mubarok \& Amini, 2019. Selain itu anak dapat melatih kemampuan berpikir logisnya. Dapat disimpulkan bahwasannya puzzle angka adalah permainan yang menyusun angka sesuai tempatnya. APE Puzzle Angka merupakan suatu alat perminan edukatif yang mengandung unsur pembelajaran menyusun angka pada tempatnya.

\section{Kecerdasan Logika Matematika}

Kecerdasan matematis-logis atau kecerdasan logika matematika (Suhendri, 2011) merupakan gabungan dari kemampuan berhitung dan kemampuan logika sehingga siswa dapat menyelesaikan suatu masalah secara logis. Kecerdasan logika matematika menurut (Meryem, 2017) adalah merupakan kecerdasan dalam menggunakan angka dan logika. Kecerdasan ini termasuk kepekaan terhadap pola logis dan hubungan, pernyataan dan proposisi, fungsi, dan abstraksi terkait lainnya. Jenis-jenis proses yang digunakan dalam layanan kecerdasan logika matematikatermasuk kategorisasi, klasifikasi, inferensi, generalisasi, perhitungan, dan pengujian hipotesis. Amstrong dengan jelas menggambarkan bahwa orang yang memiliki kecerdasan logika matematika selalu identik dengan profesi yang berhubungan dengan penggunaan angka-angka (Suripatty et al., 2019).

Anak yang memiliki kecerdasan logika matematika atau kemampuan kognitif akan lebih menonjol dalam kemampuan berpikir dan kognitifnya. Anak dengan kecerdasan logika memiliki ciri: 1) Mengingat pola abstrak; 2) Mengemukakan alasan logis secara deduktif atau induktif; 3) Memahami hungan sebab-akibat; 4) Mengerjakan teka-teki silang yang logis; 5) Menghitung diluar kepala; 6) Kritis (Suhendri \& Id, 2011).

Mufarizuddin (2017) Kecerdasan logika matematik berkaitan dengan perkembangan kemampuan berpikir sistematis, menggunakanangka, menghitung, menemukan hubungan sebab akibat, dan membuat klasifikasi. Anak yang mempunyai kelebihan dalam kecerdasan logika matematika, tertarik memanipulasi lingkungan serta cenderung menerapkan strategi coba ralat, mereka suka menduga-duga dan memiliki rasa ingin tahu yang besar (Hartini, 2012). Jadi kecerdasan logika-matematika adalah kemampuan untuk melihat, memahami angka,konsep bentuk, pola serta memecahkan masalah sederhana.

Tujuan kecerdasan logika-matematika menurut Hartini (2012): 1) Mengembangkan kemampuan mengurutkan sesuai ciri tertentu; 2) Mengembangkan kemampuan membilang, menyebutkan angka 1 sampai 10;3) Mengembangkan kemampuan perkiraan ukuran seperti: banyak-sedikit, besar-kecil dan panjang-pendek: 4) Merangsang kemampuan mengenali pola; 5) Merangsang kepekaan strategi; 6) Merangsang kemampuan mengenali bentuk-bentuk geometri. 
Tahapan-tahapan Pembelajaran Matematika menurut Hartini (2012) 1) Tingkat pemahaman konsep dimana anak akan memahami konsep melalui pengalaman beraktivitas bermain dengan benda-benda kongkrit; 2) Tingkat transisi proses berpikir yang merupakan masa peralihan dari pemahaman kongkrit menuju pengenalan lambang yang konkrit, dimana benda kongkrit itu masih ada dan mulai dikenalkan bentuk lambangnya. Hal ini harus dilakukan guru secara bertahap sesuai dengan laju dan kecepatan kemampuan anak yang secara individual berbeda; 3) Tingkat lambang bilangan tahap terakhir di mana anak diberi kesempatan untuk mengenal dan memvisualisasikan lambang bilangan atas konsep kongkrit yang telah mereka pahami. Ada saat di mana mereka masih menggunakan alat kongkrit hingga mereka melepaskannya sendiri.

Faktor yang Mempengaruhi Kecerdasan Logika-Matematika (Hartini, 2012) 1) Faktor Herediter (faktor bawaan dari keturunan). Semua anak mempunyai gen pembawa kecerdasan dengan kadar yang dapat berbeda-beda; 2) Faktor Lingkungan. Semenjak lahir anak mulai berinteraksi dengan lingkungan tempat hidupnya. Ketika panca indera mulai berfungsi anak akan semakin banyak berhubungan dengan lingkungan. Lingkungan berpengaruh besar pada kecerdasan anak; 3) Asupan Nutrisi pada Zat Makanan. Nutrisi merupakan salah satu faktor yang mendukung perkembangan kecerdasan anak. Jumlah nutrisi harus memenuhi batas kemampuan tubuh untuk menyerapnya dalam keadaan yang berlebihan, nutrisi tersebut tidak dapat diserap bagaimana fungsinya. Bahkan dapat menimbulkan efek samping yang kurang baik; 4) Aspek kejiwaan Kondisi emosi bernilai penting dalam menumbuhkan bakat dan minat anak sehingga akan sangat berpengaruh pada tingkat kecerdasan anak.

Kecerdasan logika matematika sangat erat hubungannya dengan kemampuan brpikir dan mengembangkan kemampuan pola pikir anak. Kecedasan logika matematika ini juga berkaitan dengan kemampuan menganalisis masalah dan eksperimen.

\section{Keunggulan Meningkatkan Kecerdasan Logika Matematik Melalui Media Interaktif Puzzle Angka}

Permainan merupakan salah satu faktor yang cukup penting dalam tumbuh kembang anak. Salah satunya dengan memanfaatkan penggunaan game edukasi puzzle yang dapat menunjang proses pembelajaran terhadap anak. Game puzzle adalah salah satu mainan edukatif yang dapat merangsang kemampuan logika/matematik anak yang dimainkan dengan cara membongkar pasang kepingan puzzle berdasarkan pasangannya (Arifin et al., 2018). Media interaktif mampu membuat anak lebih mengenal angka dan ikut aktif terlibat dalam pembelajaran, sehingga pembelajaran yang dilakukan lebih efektif. Penelitian lain yang dilakukan oleh (Cahyati \& Syafdaningsih, 2018) juga berhasil meningkatkan kemampuan dan perkemabangan anak melalui pemberian permainan dari media interaktif.

Media Interaktif puzzle angka menjadi kegiatan bermain edukatif guna memperoleh pengetahuan dan pengalaman belajar anak dengan cara yang menyenangkan bagi anak serta dapat membuat anak senang dalam belajar matematika. Dari permainan dengan media interaktif puzzle angka, kecerdasan logika matematika anak akan berkembang dengan baik sehingga dapat diambil kesimpulan bahwa permainan puzzle angka dapat berpengaruh terhadap kecerdasan logika matematika anak.

\section{Kekurangan Meningkatkan Kecerdasan Logika Matematik Melalui Media Interaktif Puzzle Angka}

Ketika pendidik memutuskan untuk menggunakan media interaktif sebagai bahan dan media belajar, maka pendidik harus mampu menguasai dan menggunakan media tersebut dengan baik. Media interaktif menjadi teknik belajar sambil bermain yang dikemas sesuai dengan kebutuhan anak, selain itu praktis, dan mempermudah menyampaikan materi 
(Cahyati \& Syafdaningsih, 2018) oleh sebab itu jika pendidik tidak dapat mengoperasikannya dengan baik maka pendidik malah akan mengalami kesulitan dalam menyampaikan materi.

Media interaktif puzzle angka termasuk dalam gamifikasi. Gamifikasi merupakan konsep pembelajaranyang memiliki tujuan untuk menjadikan peserta didik lebih termotivasi dengan cara memaksimalkan kegunaan elemen-elemen di dalam sebuah game. Selain itu, gamifikasi memiliki tujuan untuk kenyamanan peserta didik dalam hal belajar (Majid \& Huda, 2020). Sehingga dalam penyajiannya media interaktif ini menuntut untuk ketepatan pemberian setiap elemen dan kemampuan pendidik dalam mengemas pembelajaran guna menunjang efektivitas kemenarikan pembelajaran dengan media interaktif.

\section{SIMPULAN}

Berdasarkan hasil penelitian dapat disimpulkan bahwa kecerdasan logika matematika melalui media interaktif puzzle angka terbukti secara efektif dapat meningkat dan diterapkan dalam pembelajaran anak usia dini. Disisi lain penerapan media interaktif puzzle angka dapat mengembangkan keterampilan lain anak, mengontrol rasa cemas, memberi rasa bahagia, memberi pengalaman belajar baru yang menyenangkan, dan menjadikan anak mudah menyerap informasi yang disampaikan oleh pendidik. Oleh karena itu pemberian media interaktif puzzle angka bisa dijadikan media pembelajarn yang menunjang pengoptimalan kecerdasan logika matematika anak.

\section{UCAPAN TERIMA KASIH}

Penelitian ini dapat dilaksanakan dengan baik berkat bantuan dari berbagai pihak. Untuk itu kami selaku tim peneliti mengucapkan terimakasih kepada seluruh pihak yang terkait dan yang membantu sehingga proses penelitian ini dapat berjalan dengan lancar.

\section{DAFTAR PUSTAKA}

Apriliani, E. I., Purwanti, K. Y., \& Riani, R. W. (2020). Peningkatan Kesantunan Bahasa Anak Usia Dini melalui Media Pembelajaran Interaktif Budaya Jawa. Jurnal Obsesi : Jurnal Pendidikan Anak Usia Dini, 5(1), 150. https:// doi.org/10.31004/obsesi.v5i1.319

Arifin, B., -, Z., \& Sifaunajah, A. (2018). Aplikasi Game Puzzle Pengenalan Perangkat $\begin{array}{llll}\text { Komputer } \quad \text { Berbasis } & \text { Android. }\end{array}$ https:// doi.org/10.32764/saintekbu.v10i2.207

Cahyati, N., \& Syafdaningsih, R. (2018a). Pengembangan Media Interaktif Dalam Pengenalan Kata Bermakna Pada Anak. In Cakrawala Dini (Vol. 9, Issue 2). https://doi.org/10.17509/cd.v9i2.11339

Zaini, H., \& Dewi, K. (2017). Pentingnya Media Pembelajaran Untuk Anak Usia Dini. Raudhatul Athfal: Jurnal Pendidikan Islam Anak Usia Dini, 1(1), 81-96. https:// doi.org/10.19109/ra.v1i1.1489

Hartini, P. (2012). Peningkatan Kemampuan Matematika Anak Melalui Media Permainan Memancing Angka Di Taman Kanak-Kanak Fathimah Bukareh Agam. Jurnal Pesona PAUD, 1(1).

Kristianti, N., Niwayan Purnawati, S., \& Suyoto. (2018). Virtual education with puzzle games for early childhood: A study of Indonesia. International Journal of Engineering Pedagogy, 8(2), 14-22. https://doi.org/10.3991/ijep.v8i2.7943

Lestariningrum, A., Crie Handini, -myrnawati, Nusantara PGRIKediri, P.-Paudu., \& Jakarta, Pp. (2017). Analisis Pengembangan Kecerdasan Logis Matematis Anak Usia 5-6 Tahun Menggunakan Permainan Tradisional. https://doi.org/10.21009/JPUD.112

Majid, H. T., \& Huda, S. N. (2020). Gamifikasi Pembelajaran Huruf Hijaiyah dan Bahasa Arab: Studi Kasus PAUD Terpadu Mutiara Yogyakarta. https://journal.uii.ac.id/AUTOMATA/article/view/15583 
Meryem, C. (2017). Examination of children decision making using clues during the logical reasoning process. Educational Research and Reviews, 12(16), 783-788. https:// doi.org/10.5897/ERR2017.3297

Mufarizuddin, M. (2017a). Peningkatan Kecerdasaan Logika Matematika Anak melalui Bermain Kartu Angka Kelompok B di TK Pembina Bangkinang Kota. Jurnal Obsesi : Jurnal Pendidikan Anak Usia Dini, 1(1), 62. https://doi.org/10.31004/obsesi.v1i1.32

Mufarizuddin, M. (2017b). Peningkatan Kecerdasaan Logika Matematika Anak melalui Bermain Kartu Angka Kelompok B di TK Pembina Bangkinang Kota. Jurnal Obsesi : Jurnal Pendidikan Anak Usia Dini, 1(1), 62. https:// doi.org/10.31004/obsesi.v1i1.32

Munawaroh, H., Widiyani, A. Y. E., \& Muntaqo, R. (2020). Pengembangan Multimedia Interaktif Tema Alam Semesta pada Anak Usia 4-6 Tahun. Jurnal Obsesi: Jurnal Pendidikan Anak Usia Dini, 5(2), 1164-1172. https://doi.org/10.31004/obsesi.v5i2.619

Mustajab, M., Baharun, H., \& Iltiqoiyah, L. (2020). Manajemen Pembelajaran melalui Pendekatan BCCT dalam Meningkatkan Multiple intelligences Anak. Jurnal Obsesi : Jurnal Pendidikan Anak Usia Dini, 5(2), 1368-1381. https://doi.org/10.31004/obsesi.v5i2.781

Kuntjojo, \& Wijaya, I. P. (2018). Model Asesmen Informal Kecerdasan Jamak Anak Usia 4 - 5 Tahun. Jurnal Pendidikan Usia Dini, 12(1), 88 - 103. https://doi.org/10.21009//JPUD.121.08

Setiawan, A., Praherdhiono, H., \& Suthoni, S. (2019). Penggunaan Game Edukasi Digital Sebagai Sarana Pembelajaran Anak Usia Dini. JINOTEP (Jurnal Inovasi Dan Teknologi Pembelajaran) Kajian Dan Riset Dalam Teknologi Pembelajaran, 6(1). https:// doi.org/10.17977/um031v6i12019p039

Sholihah, K. (2018). Meningkatkan Kemampuan Berpikir Logis Pada Anak Usia Dini Dengan Menggunakan Media Puzzle Angka. CERIA (Cerdas Energik Responsif Inovatif Adaptif), 1(5), 2714-4107. https://doi.org/10.22460/ceria.v1i5.p13-22

Suhendri, H., \& Id, H. C. (2011). Pengaruh Kecerdasan Matematis-Logis Dan Kemandirian Belajar Terhadap Hasil Belajar Matematika. In Jurnal Formatif, 1(1). https://doi.org/10.30998/formatif.v1i1.61

Sujarweni, W. Wiratna. (2019). Metodologi Penelitian. Yogyakarta: Pustaka Baru Press

Suripatty, P. J. P., Nadiroh, N., \& Nurani, Y. (2019). Peningkatan Kecerdasan Logika Matematika melalui Permainan Bingo. Jurnal Obsesi : Jurnal Pendidikan Anak Usia Dini, 4(1), 100. https:// doi.org/10.31004/obsesi.v4i1.282

Susilawati, B., \& Satriawan, D. (2018). Membangun Media Interaktif Belajar Anak Usia Dini Dalam Mengenal Huruf dan Angka. Al-Athfaal: Jurnal Ilmiah Pendidikan Anak Usia Dini, 1(1). https://doi.org/10.24042/ajipaud.v1i1.3059

Syukron Al Mubarok, A. A., \& Amini, A. (2019). Kemampuan Kognitif dalam Mengurutkan Angka melalui Metode Bermain Puzzle Angka. Jurnal Obsesi : Jurnal Pendidikan Anak Usia Dini, 4(1), 77. https:// doi.org/10.31004/obsesi.v4i1.221

Yildiz, M., Öntürk, Y., \& Efek, E. (2020). The Investigation of Multiple Intelligence Modalities of University Students Receiving Sports Education. Asian Journal of Education and Training, 6(2), 246-255. https://doi.org/10.20448/journal.522.2020.62.246.255

Zaini, H., \& Dewi, K. (2017). Pentingnya Media Pembelajaran Untuk Anak Usia Dini. Raudhatul Athfal: Jurnal Pendidikan Islam Anak Usia Dini, 1(1), 81-96. https://doi.org/https://doi.org/10.19109/ra.v1i1.1489

Zamroni. (2020). Smart Parenting In Improving Students' Spiritual Intelligence In PesantrenBased Madrasahs, Ta'dib, 23(1) https://doi.org/10.31958/jt.v23i1.1947 